Atmos. Chem. Phys., 13, 2423-2434, 2013

www.atmos-chem-phys.net/13/2423/2013/

doi:10.5194/acp-13-2423-2013

(C) Author(s) 2013. CC Attribution 3.0 License.

\title{
Black carbon vertical profiles strongly affect its radiative forcing uncertainty
}

\author{
B. H. Samset ${ }^{1}$, G. Myhre ${ }^{1}$, M. Schulz ${ }^{2}$, Y. Balkanski ${ }^{3}$, S. Bauer ${ }^{4}$, T. K. Berntsen ${ }^{1}$, H. Bian ${ }^{5}$, N. Bellouin ${ }^{6}$, T. Diehl ${ }^{7,8}$, \\ R. C. Easter ${ }^{9}$, S. J. Ghan ${ }^{9}$, T. Iversen ${ }^{2,11,16}$, S. Kinne ${ }^{10}$, A. Kirkevåg ${ }^{2}$, J.-F. Lamarque ${ }^{12}$, G. Lin ${ }^{13}$, X. Liu ${ }^{9}$, \\ J. E. Penner ${ }^{13}$, Ø. Seland ${ }^{2}$, R. B. Skeie ${ }^{1}$, P. Stier ${ }^{14}$, T. Takemura ${ }^{15}$, K. Tsigaridis ${ }^{4}$, and K. Zhang ${ }^{9,10}$ \\ ${ }^{1}$ Center for International Climate and Environmental Research - Oslo (CICERO), Oslo, Norway \\ ${ }^{2}$ Norwegian Meteorological Institute, Oslo, Norway \\ ${ }^{3}$ Laboratoire des Sciences du Climat et de l'Environnement, CEA-CNRS-UVSQ, Gif-sur-Yvette, France \\ ${ }^{4}$ NASA Goddard Institute for Space Studies and Columbia Earth Institute, New York, NY, USA \\ ${ }^{5}$ Joint Center for Earth Systems Technology, University of Maryland Baltimore County, MD, USA \\ ${ }^{6}$ Met Office Hadley Centre, Exeter, UK \\ ${ }^{7}$ NASA Goddard Space Flight Center, Greenbelt, MD, USA \\ ${ }^{8}$ Universities Space Research Association, Columbia, MD, USA \\ ${ }^{9}$ Pacific Northwest National Laboratory, Richland, WA, USA \\ ${ }^{10}$ Max Planck Institute for Meteorology, Hamburg, Germany \\ ${ }^{11}$ Department of Geosciences, University of Oslo, Oslo, USA \\ ${ }^{12}$ NCAR Earth System Laboratory, National Center for Atmospheric Research, Boulder, CO, USA \\ ${ }^{13}$ Department of Atmospheric, Oceanic, and Space Sciences, University of Michigan, Ann Arbor, Michigan, USA \\ ${ }^{14}$ Department of Physics, University of Oxford, Oxford, UK \\ ${ }^{15}$ Research Institute for Applied Mechanics, Kyushu University, Fukuoka, Japan \\ ${ }^{16}$ ECMWF, Shinfield Park, RG2 9AX, Reading, UK
}

Correspondence to: B. H. Samset (b.h.samset@cicero.uio.no)

Received: 22 October 2012 - Published in Atmos. Chem. Phys. Discuss.: 7 November 2012

Revised: 8 February 2013 - Accepted: 12 February 2013 - Published: 1 March 2013

\begin{abstract}
The impact of black carbon (BC) aerosols on the global radiation balance is not well constrained. Here twelve global aerosol models are used to show that at least $20 \%$ of the present uncertainty in modeled $\mathrm{BC}$ direct radiative forcing $(\mathrm{RF})$ is due to diversity in the simulated vertical profile of BC mass. Results are from phases 1 and 2 of the global aerosol model intercomparison project (AeroCom). Additionally, a significant fraction of the variability is shown to come from high altitudes, as, globally, more than $40 \%$ of the total $\mathrm{BC}$ RF is exerted above $5 \mathrm{~km}$. $\mathrm{BC}$ emission regions and areas with transported $\mathrm{BC}$ are found to have differing characteristics. These insights into the importance of the vertical profile of BC lead us to suggest that observational studies are needed to better characterize the global distribution of $\mathrm{BC}$, including in the upper troposphere.
\end{abstract}

\section{Introduction}

Unlike most atmospheric aerosols, black carbon (BC) absorbs solar radiation. This warming effect of $\mathrm{BC}$ has led to suggestions, both in the scientific community (Editorial Nature, 2009; Grieshop et al., 2009; Shindell et al., 2012; Hansen et al., 2000) and among policy makers, for reduction of $\mathrm{BC}$ emissions to mitigate global warming. The uncertainties in the radiative forcing $(\mathrm{RF})$ of the direct aerosol effect of BC are however large (Ramanathan and Carmichael, 2008; Schulz et al., 2006; Feichter and Stier, 2012), hampering mitigation studies (Koch et al., 2011a). Among the causes of these model uncertainties are assumptions about the vertical concentration profiles of BC (Zarzycki and Bond, 2010). There are also significant discrepancies between models and observations (Koch et al., 2009). 
Aerosol radiative forcing is a measure of the effect a given change in aerosol concentrations has on the atmospheric energy balance. The efficiency with which $\mathrm{BC}$ can induce RF is however dependent on external factors such as surface albedo, water vapor, background aerosol distributions and, most notably, the presence of clouds (Haywood and Shine, 1997; Zarzycki and Bond, 2010). The BC forcing is therefore highly sensitive to the full 3-D distribution of BC concentration (Samset and Myhre, 2011). Anthropogenic direct BC forcing estimated by the current major global aerosol models varies between $0.05 \mathrm{Wm}^{-2}$ and $0.38 \mathrm{Wm}^{-2}$ (Myhre et al., 2013). This range is similar to earlier estimates (Schulz et al., 2006; Feichter and Stier, 2012), and difficulties in reducing the range highlights the urgent need to understand the different causes of this model variability in BC forcing.

Several studies have previously indicated that the vertical transport is one area where the models still differ significantly (Koffi et al., 2012; Schwarz et al., 2010; Textor et al., 2006, 2007). This study uses input from 12 global aerosol models participating in the AeroCom model intercomparison project to compare and study the impacts of modeled $\mathrm{BC}$ vertical forcing profiles. By combining the models' own concentration profiles with a common 4-D (spatial and temporal) efficiency profile (EP) of RF per gram of $\mathrm{BC}$, we here recalculate and compare the exerted $\mathrm{RF}$ of the $\mathrm{BC}$ direct aerosol effect at various altitudes and spatial regions. By comparing calculations using the full 4-D in clear and cloudy skies with analyses using global and annual mean profiles, we can also isolate the contributions from the cloud field and variations due to regional differences.

\section{Data}

The AeroCom initiative asks models to simulate the direct aerosol radiative effect under as similar conditions as possible. All models run single year simulations using the same base years for aerosol emissions (2000 and 1850), with unchanged meteorology to exclude indirect effects. Both circulation models and transport models have participated. Two sets of model intercomparisons have been performed, here labeled AeroCom Phase 1 (Dentener et al., 2006; Textor et al., 2006; Schulz et al., 2006) and AeroCom Phase 2 (Myhre et al., 2013). See the references or the main AeroCom website (aerocom.met.no) for details.

For the present study, 4-D (spatial and temporal) BC concentration fields from 12 global aerosol models participating in AeroCom Phase 2 are used. For six of the models, concentration fields of $\mathrm{BC}$ from fossil and biofuel burning only (BCFF) are also used. The 1850 concentrations are subtracted from the 2000 ones, leaving the contribution due to anthropogenic BC or BCFF emissions. Unless otherwise stated, all results below are for anthropogenic aerosols only.

Three of the same modeling groups also provided BC concentration profiles to AeroCom Phase 1, and these fields are also included here. The IMPACT model has not undergone major changes between the AeroCom phases, and for CAM4-Oslo the changes related to the treatment of $\mathrm{BC}$ are small. The OsloCTM2 model has however been heavily revised with the addition of both an ageing scheme for $\mathrm{BC}$ and improved treatment of BC washout between P1 and P2.

From AeroCom P2, participating models are NCARCAM3.5 (Lamarque et al., 2012), CAM4-Oslo (Kirkevåg et al., 2013), CAM5.1 (Liu et al., 2012), GISS-modelE (Koch et al., 2011b), GMI (Bian et al., 2009), GOCART-v4 (Chin et al., 2009), HadGEM2 (Bellouin et al., 2011), IMPACT (Lin et al., 2012), INCA (Szopa et al., 2012), ECHAM5-HAM (Zhang et al., 2012), OsloCTM2 (Skeie et al., 2011) and SPRINTARS (Takemura et al., 2005). From AeroCom P1, participating models are CCM-Oslo (Kirkevag and Iversen, 2002) (earlier version of CAM4-Oslo, denoted UiO_GCM in AeroCom P1), IMPACT (Liu et al., 2005) and OsloCTM2 (denoted as UiO_CTM in AeroCom P1) (Myhre et al., 2003).

\section{Methods}

\subsection{4-dimensional forcing efficiency profiles}

Samset and Myhre (2011) presented a set of vertical profiles of the aerosol direct radiative specific forcing (forcing per unit mass) for BCFF, i.e. the amount of top-of-atmosphere shortwave radiative forcing exerted per gram of aerosols at a given altitude. The profiles are for a particular model, the OsloCTM2, running under AeroCom P2 configuration. Here we term these efficiency profiles (EP). In the literature, the term normalized radiative forcing is also commonly used. We here employ the full 4-D efficiency profiles, either for all sky or clear sky conditions. For each model grid point and time step, we multiply the modeled BC concentration by the OsloCTM2 EP to get the contribution to the total shortwave, top-of-atmosphere BC radiative forcing. This gives us intercomparable 4-D RF fields, something that is not immediately available from each model.

Differences in model specific treatment of clouds, water uptake and microphysics are not treated by this method, i.e. they correspond to the ones for OsloCTM2. We are left solely with variations due to the concentration profiles and the total aerosol burden of the host models. We label this the recalculated RF, to emphasize that it is heavily correlated with the burden and should not be taken directly as an estimate of BC forcing of each model. Since the model that was used to produce the profiles of RF per gram has among the strongest global mean forcing efficiencies (Myhre et al., 2013), most recalculated RFs can be expected to be stronger than their host model would predict. However, by dividing the recalculated RF by the total aerosol burden of the host model, we extract the variability in specific forcing that is due only to the vertical profile of $\mathrm{BC}$ produced by the host model in conjunction with the OsloCTM2 efficiency profile. We can 


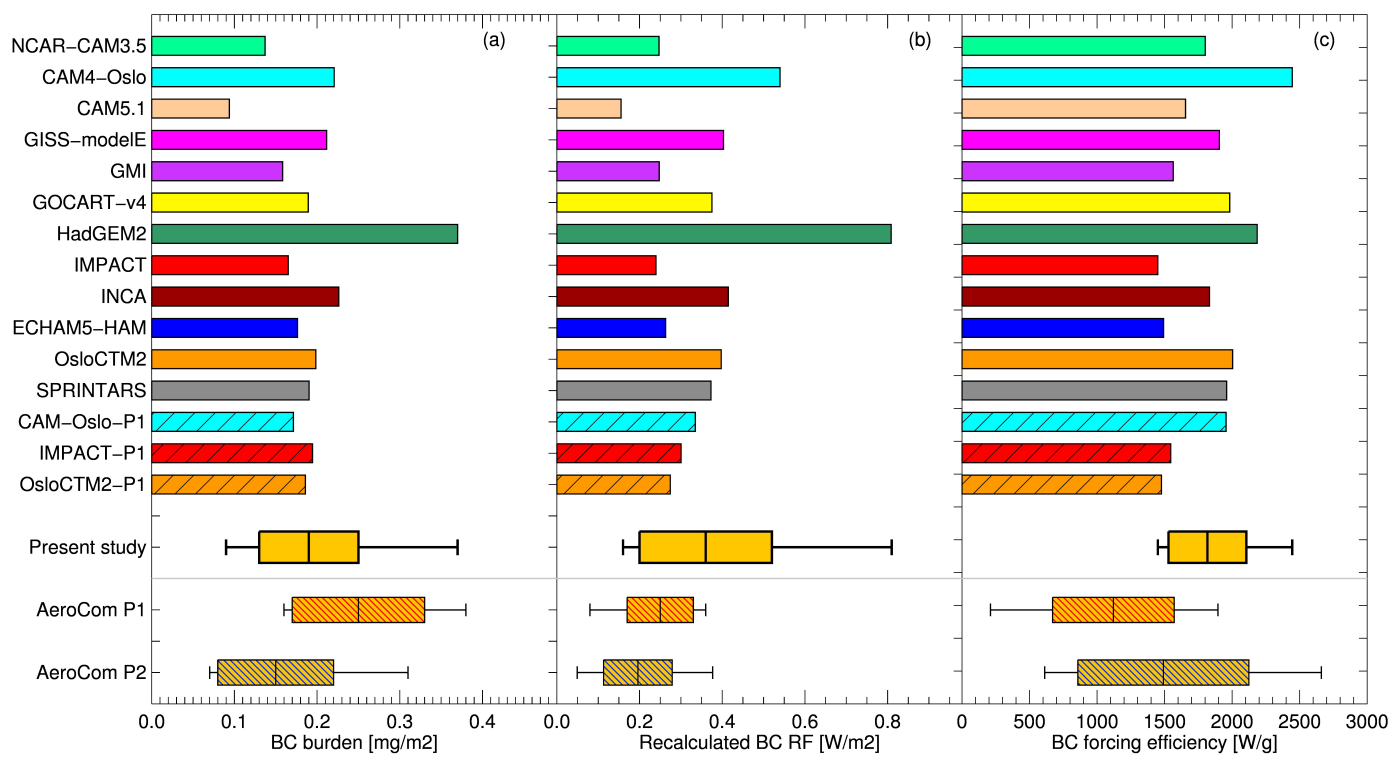

Fig. 1. Modeled BC global mean (a) burden, (b) RF and (c) forcing efficiency. Yellow boxes indicate mean, one standard deviation and max/min values. Mean values and spreads for AeroCom P1 and P2 (hatched whisker boxes) are taken from Schulz et al. (2006) and Myhre et al. (2013) respectively.

subsequently use the vertical RF profiles to study this variability (see Sect. 4.1).

The remaining variability in specific forcing contains information on regional differences (high or low surface albedo, indigenous emissions, transport region or both, cloud fields), and aerosol optical properties and mixing rules. To separate these effects, we ran parallel analyses using only a global mean profile of RF per unit mass, a distinct profile of RF per unit mass for clear sky conditions, or a combination of clear sky conditions and a global profile.

\subsection{Region definitions}

A set of illustrative regions is chosen for some of the results and discussion below. "Europe" is defined as the box covering longitudes -10 to 30 , latitudes 38 to 60 . "China" covers longitudes 105 to 135 , latitudes 15 to 45 . "Arctic" covers latitudes 70 to 90, all longitudes. Europe and China represent regions with high industrial $\mathrm{BC}$ emissions and significant fractions of the global BCFF emissions, making their total BC forcing sensitive to pure vertical transport and wet scavenging. The Arctic is a region with low indigenous emissions, but important $\mathrm{BC}$ contributions at high altitudes transported from other regions. Its total $\mathrm{BC}$ forcing is therefore sensitive to model differences in vertical and long range $\mathrm{BC}$ transport and removal.

\section{Results}

\subsection{RF variability due to vertical profiles}

We first quantify the fraction of the total modeled RF variability attributable to vertical profiles alone. Figure 1a shows the global mean anthropogenic BC burden from models participating in AeroCom Phase 2, in addition to three models from AeroCom Phase 1 included to investigate the magnitude of variability due to model developments. We find a multi-model mean of $0.19 \mathrm{mg} \mathrm{m}^{-2}$, but with a relative standard deviation (RSD) of $32 \%$ and a model spread from 0.09 to $0.37 \mathrm{mg} \mathrm{m}^{-2}$. Table 1 lists the numbers for individual models. Under an assumption of equal specific forcing, this alone will cause a large diversity in the total $\mathrm{BC}$ forcing predicted by the models. AeroCom Phases 1 and 2 found a similar burden range, as shown by the whisker boxes in Fig. 1a. Note that the AeroCom P1 includes BC from all sources, i.e. including biomass burning, while $\mathrm{P} 2$ results are for $\mathrm{BC}$ from fossil and biofuel burning (BCFF) sources only. This causes the P2 burden and RF means to be lower than for P1. Figure $1 \mathrm{~b}$ shows the RF for each model, recalculated from the concentration profiles using the common EP from OsloCTM2 (Samset and Myhre, 2011). We find a stronger mean RF than from either of the AeroCom phases. This is partly due to the strength of the EP used, which is higher than for most AeroCom models, and partly to the fact that the present study includes $\mathrm{BC}$ from biomass burning as mentioned above. See Discussion for further comments.

The recalculated RF values are highly correlated with the burden values(Pearson corr. coeff. $\rho=95 \%$ ), as expected 

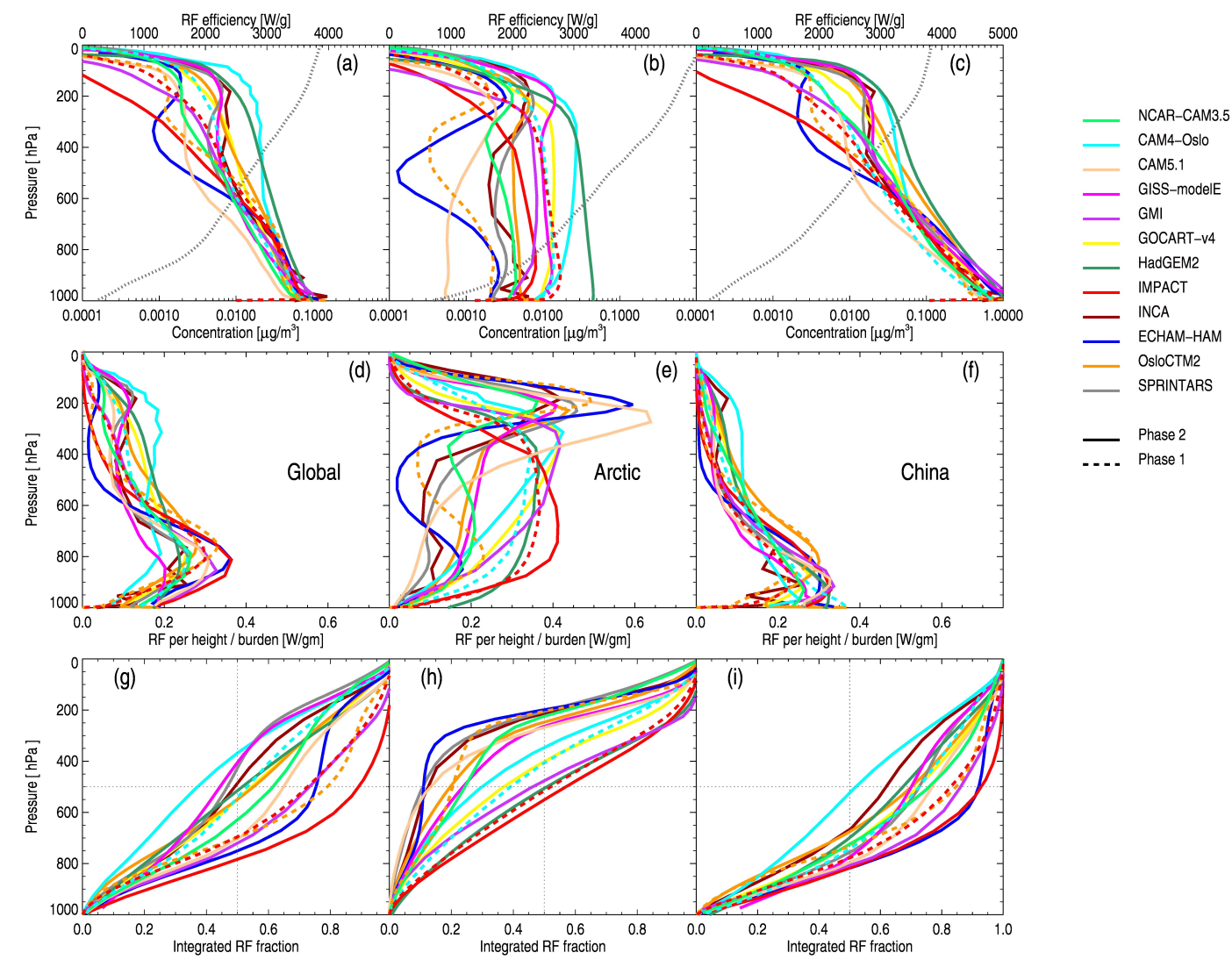

Fig. 2. Comparison of modeled concentration and RF profiles. (a-c) BC concentration vertical profiles, global mean and for two selected regions. Overlain is the annual mean forcing efficiency profile for the selected region (grey dashed line). Solid lines show AeroCom P2 submissions, dashed lines show P1. (d-f) BC RF per height, divided by the modeled global mean BC burden, globally and for three selected regions. (g-i) Vertical profile of integrated absolute BC RF. Lines indicate the $50 \%$ mark and $500 \mathrm{hPa}$ altitude.

since a common EP is used. However, dividing the recalculated RF by the global mean burdens gives global estimates of $\mathrm{BC}$ forcing efficiency (radiative forcing exerted per gram of $\mathrm{BC}$ aerosol), that are independent of the burden value simulated by the host model. This is shown in Fig. 1c. If the modeled spatial and temporal aerosol distributions, notably the vertical profiles, were also identical or merely related by a simple scaling, this spread would vanish. The remaining diversity therefore carries information on the impact of the 4-D $\mathrm{BC}$ concentration profiles on the model RF spread, separate from the variability due to burden differences.

In the following paragraph we quantify the contribution of the vertical profile to total model spread. Our method is to calculate the relative standard deviation (RSD) of the residual variability, after normalizing the recalculated RF by the model burdens. We then compare this to RSDs from the native model RF estimates. First, note that there is a residual variability in the forcing efficiency (Fig. 1c) that is due to the variations in the 4-D (spatial and temporal) aerosol mass distributions, with a relative standard deviation (RSD) of $16 \%$. This number is dominated by the vertical distributions, but will also have components from horizontal and temporal variability in the aerosol fields between models. To isolate the contribution from vertical distributions, we performed the analysis using global mean BC and efficiency profiles per month, averaging out any horizontal differences, and then using global, annual mean profiles, to also remove temporal variability. The resulting RSD from vertical profiles alone is found to be $13 \%$.

Next, we compare this to variability on forcing per burden in AeroCom P1 and P2, which in both cases is around $40 \%$. Our residual RSD from vertical profiles is therefore approximately $30 \%$ of the variability values from both these studies. However, three models in P2 have mass extinction coefficients that deviate significantly from recommendations given in the literature (Bond et al., 2006) and thus unduly influence the RSD. Removing contributions from these three models reduces the RSD on the forcing per burden to $32 \%$, subsequently increasing our estimate of the variability due to vertical profiles to $40 \%$.

Finally, we need to relate this to the total model RF variability. Assuming that RF variability is in some way a combination of variability in burden and forcing efficiency, we first note that in P1 and P2 these two factors have approximately 


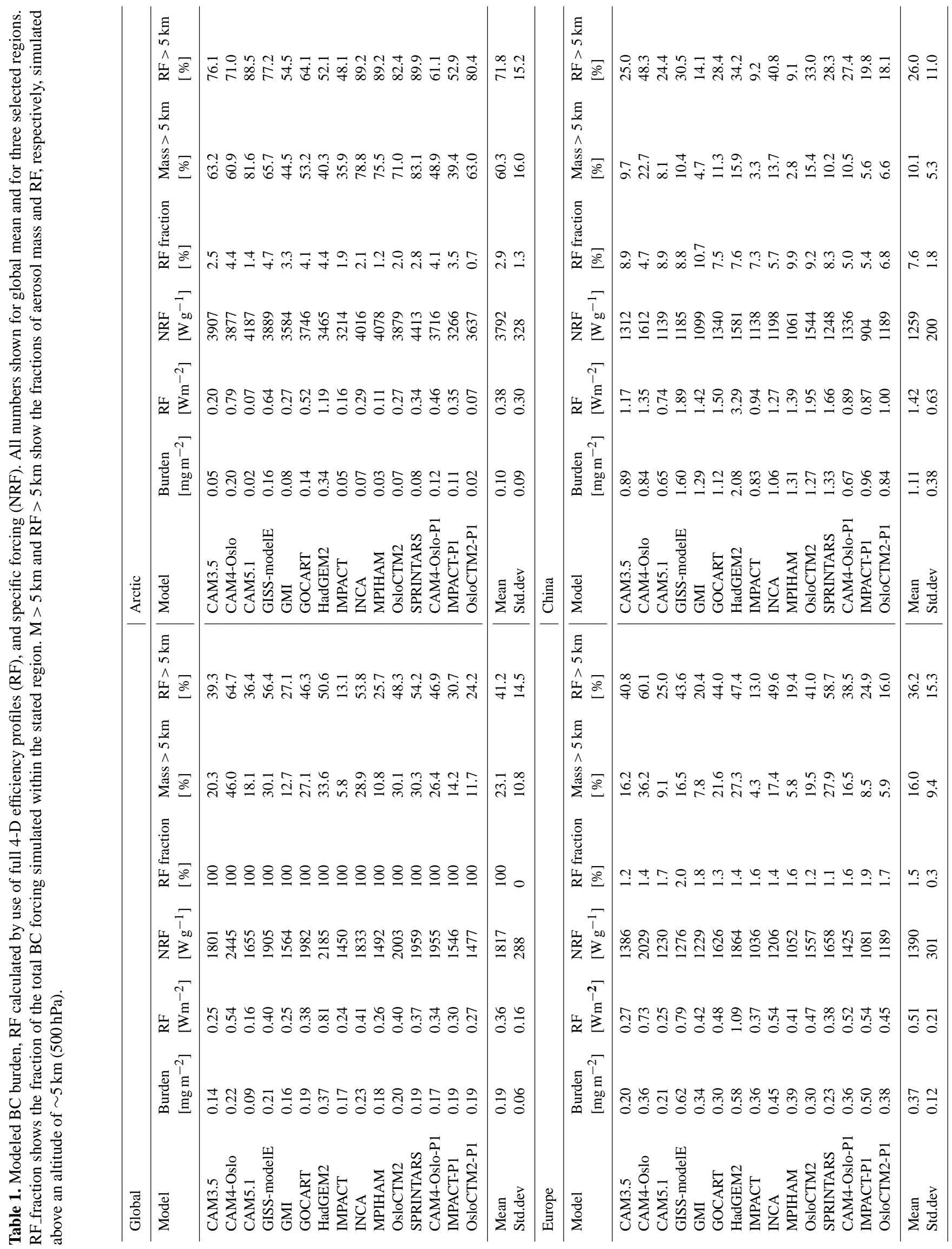


equal RSDs. If they were uncorrelated the vertical distribution could therefore be said to contribute half of the total variability on RF, which from our above calculation is $20 \%$. This is however not the case. We will show below that $20 \%$ can instead be considered a lower limit.

To investigate the correlation of variability in burden and forcing efficiency, we note that in both AeroCom P1 and P2, the burdens and forcing efficiencies are weakly anticorrelated. This is apparent from the fact that the RSD on the RF (shown in Fig. 1) is lower than it would be if the errors on burden and forcing per burden were uncorrelated. Quantifying this effect using numbers from AeroCom P2, we find a weak Pearson correlation coefficient of $\rho=-0.46$ (or -0.40 if we again remove the three outlier models).

In the present analysis, we can estimate the impact of the vertical distributions by the fraction of mass simulated above $500 \mathrm{hPa}$, or approximately $5 \mathrm{~km}$, shown in Table 1 as M5k. M5k is calculated by integrating the $\mathrm{BC}$ vertical profiles presented in Fig. 2a for model layers above or below an average pressure of $500 \mathrm{hPa}$, and then taking the ratio of these values. We observe that M5k is strongly correlated with the recalculated $\operatorname{RF}(\rho=0.70)$ and forcing per burden $(\rho=0.97)$, as expected due to the efficiency profile used for the present analysis. However M5k is also weakly positively correlated with the total burden $(\rho=0.48)$. The vertical distribution variability therefore does not contribute to the observed anticorrelation between burden and forcing per burden in AeroComP1 and $\mathrm{P} 2$.

We can assume that forcing per burden is determined by a combination of the vertical profile (positive correlation with burden) and a set of uncorrelated global variables such as $\mathrm{BC}$ optical properties (which must then have a combined negative correlation with burden). The variability on $\mathrm{BC}$ RF would be higher if the models had not compensated for high burden with a low forcing efficiency and vice versa. Since the vertical variability rather leads to a high efficiency for a high burden, its impact on the RF variability is likely stronger than the minimum estimate of $20 \%$ above. The present analysis does not allow for rigorous quantification, but it is unlikely to be larger than the $50 \%$ of the variability on total BC $\mathrm{RF}$ caused by forcing per burden. Hence we have a range of $20 \%$ to $50 \%$ of the variability of modeled BC RF caused by differences in vertical distributions.

\subsection{Comparison of modeled RF profiles}

Next we compare global and regional $\mathrm{BC}$ vertical profiles and EPs. As also shown in previous model comparisons (Schwarz et al., 2010; Textor et al., 2006, 2007), there are large differences in the modeled $\mathrm{BC}$ concentrations. Figure $2 \mathrm{a}-\mathrm{c}$ shows the annual mean vertical profiles of $\mathrm{BC}$ concentration from all models, globally and for two selected regions (Arctic and China). Globally, the concentrations quickly decrease with altitude while the forcing efficiency increases. The Arctic is a region with negligible in- digenous $\mathrm{BC}$ emissions, but where the effects of transported aerosols are relevant (Shindell et al., 2008). While all models show a significant $\mathrm{BC}$ contribution at high altitudes the model spread in the Arctic is significant, ranging from virtually constant below $200 \mathrm{hPa}$ to double-peaked structures with maxima at $900 \mathrm{hPa}$ and $200 \mathrm{hPa}$. This highlights the differences in transport and wet removal schemes between the climate models. AeroCom P1 and P2 models can be seen to perform similarly where we are able to compare. China has large surface emissions of $\mathrm{BC}$, and also sees contributions from transport at high altitudes, as is evident from Fig. 2c.

Figure $2 \mathrm{~d}-\mathrm{f}$ shows the corresponding recalculated forcing as a function of altitude, divided by model layer height to remove differences due to the models' vertical resolution.To highlight the vertical dependence, we have also normalized the profiles by the modeled global mean burden. The resulting vertical profiles illustrate at what altitudes RF is exerted. Globally, RF can be seen to be mostly exerted in a range around $800 \mathrm{hPa}$ for most models, with a secondary peak between $400 \mathrm{hPa}$ and $200 \mathrm{hPa}$ for some models. The China region follows the global pattern, but with the low altitude peak closer to the ground, reflecting the emissions there. The Arctic region, however, has a strong peak at high altitudes for most models, evidencing the relative importance of high altitude BC RF there. These features are explainable by the differences in regional concentration and forcing efficiency profiles shown in Fig. 2a-c.

Figure $2 \mathrm{~g}-\mathrm{i}$ illustrates the model spread in accumulated forcing, by integrating the absolute forcing per model layer from the surface and upwards. Globally, several of the models exert $50 \%$ of their forcing above $5 \mathrm{~km}$; however there is a large spread around this value. Regionally, this picture is quite different. In the Arctic all models have a significant forcing component above $5 \mathrm{~km}$, due both to a high fraction of aerosol at high altitudes and a strong forcing efficiency caused by high surface albedo. For the industrial regions of China the opposite is true, with the bulk of the aerosol located close to the ground where the forcing efficiency is weak.

\subsection{RF fraction exerted at high altitudes}

We find, in general, that a significant fraction of modeled BC $\mathrm{RF}$ is exerted at high altitudes, with a notable regional pattern. Figure 3 maps the model mean fraction of aerosol mass (Fig. 3a) and induced forcing (Fig. 3b) from model layers of altitude above $500 \mathrm{hPa}$, or approximately $5 \mathrm{~km}$. Firstly, the distinction between $\mathrm{BC}$ emission regions and regions with mostly transported $\mathrm{BC}$ is evident. The former have small mass and RF fractions at high altitudes, typically $10-20 \%$, while transport regions show RF fractions up to $80 \%$. Figure $3 \mathrm{c}$ compares the global and regional (Arctic, China and Europe) mean values of the mass and RF fractions. Note that the fraction of RF above $5 \mathrm{~km}$ is systematically higher than the mass fraction, due to the strongly increasing shape of the RF efficiency profiles. Globally, more than $40 \%$ of the model 

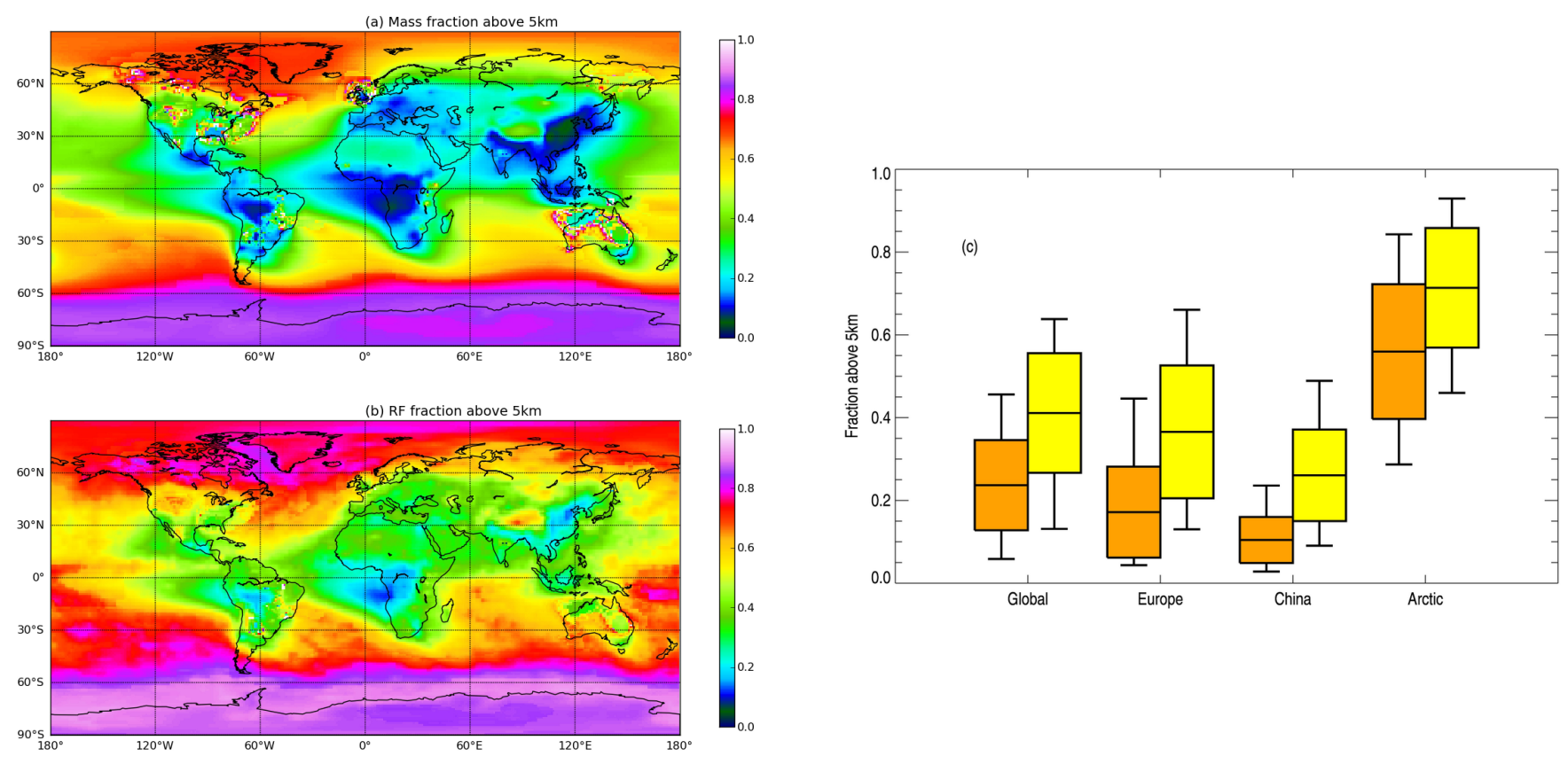

Fig. 3. Black carbon mass and induced forcing at high altitudes. (a) Fraction of modeled BC mass above $5 \mathrm{~km}$. (b) Fraction of modeled BC $\mathrm{RF}$ originating above $500 \mathrm{hPa}(5 \mathrm{~km})$. (c) Mean fraction of mass (orange) and RF (yellow) globally and for three selected regions. Boxes indicate one standard deviation on the model spread, whiskers show maximum and minimum values.

simulated RF from BC comes from model layers above $5 \mathrm{~km}$, while only $24 \%$ of the mass is found in this region. This illustrates the importance of validating model vertical profiles and transport codes not only in industrial regions, but also in transport regions with low indigenous $\mathrm{BC}$ emissions.

Figure 4 shows the RF and mass fractions in four altitude bands, globally and for the three regions. Selected bands are up to $800 \mathrm{hPa}, 800-500 \mathrm{hPa}, 500-250 \mathrm{hPa}$ and above $250 \mathrm{hPa}$, or approximately $0-2 \mathrm{~km}, 2-5 \mathrm{~km}, 5-10 \mathrm{~km}$ and above $10 \mathrm{~km}$. Altitudes are chosen by finding the model layer with a global mean pressure that closest approximates the desired height. Such information is useful for comparing models with observational data, which are typically given for given altitude bands. This can in turn aid future constructions of best estimates for global BC forcing. We note that the pattern of high variability between model estimates of burden and forcing is apparent in all four bands chosen.

\subsection{Variability in forcing efficiency due to clouds and regional differences}

We have shown that, even on global mean, a significant fraction of the variability in the BC specific forcing is due to differences in vertical profiles when applying a common EP. It is instructive to further divide this variability into the components that make up the efficiency profiles. In Fig. 5a we show the zonal mean recalculated forcing efficiency for all models, and investigate the relative importance of the cloud field and of regional differences in albedo for the resulting spread. In
Fig. 5c we have run the analysis using a global, annual mean efficiency profile instead of the full 4-D profile, and in addition used clear sky conditions. The forcing efficiency has a weak but non-vanishing model spread, and is only weakly dependent on latitude since the effects of varying surface albedo, which normally strongly increases the forcing efficiency at the poles, are averaged out in the global profile. Not all vertical sensitivity of $\mathrm{BC}$ forcing is due to the aerosols being above or below clouds (Samset and Myhre, 2011). The remainder, caused predominantly by Rayleigh scattering, water vapor and the competing effects of other aerosols, is the cause of the variability here. RSD on global mean values is $10 \%$ (see Fig. 5b). Figure 5d shows the same analysis using the full 3-D efficiency profile. The RSD increases to $13 \%$, and we now see the latitudinal effects of the high polar planetary albedo. Figure 4e shows the analysis using the global mean efficiency profile again, but under all-sky conditions. Again the RSD increases to $13 \%$, due to the cloud field. The model variability in forcing efficiency that is due to vertical profile differences can therefore be decomposed into three factors: Equal and significant contributions from the cloud field and from regional differences, and a major contribution from the underlying sensitivity of $\mathrm{BC}$ forcing to altitude even in the absence of clouds and albedo differences. Harmonizing model treatment of clouds and albedo is therefore not sufficient to remove uncertainties in $\mathrm{BC}$ forcing due to vertical profiles, highlighting the importance of ongoing aerosol model intercomparisons emphasizing other sources of variability (Stier, 2012). Combining the effects of clouds 

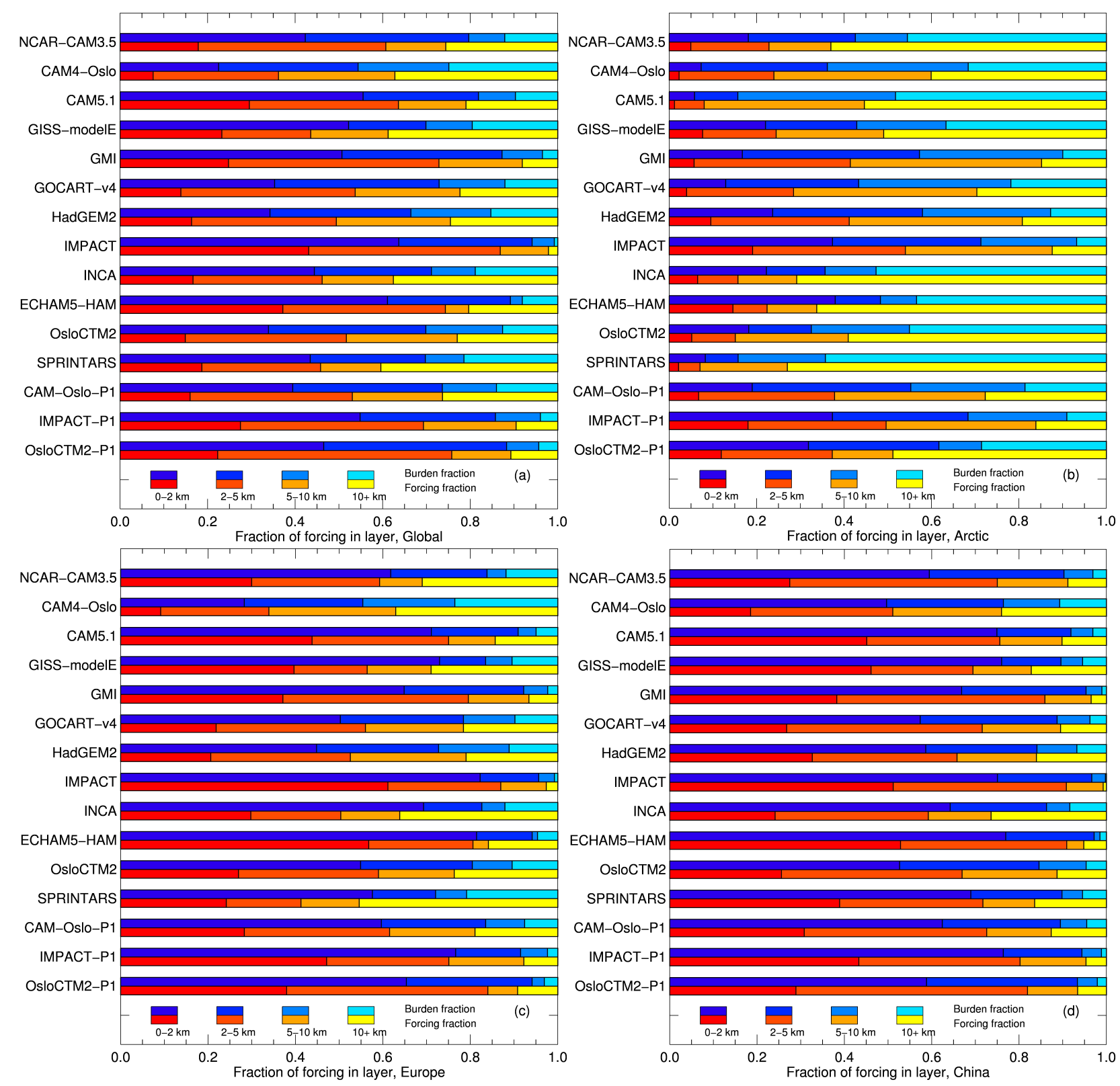

Fig. 4. Mass and forcing fractions in four altitude bands, globally and for three regions. Upper rows show burden fractions in blues, lower rows show RF fractions in reds. (a) Global mean, (b) Arctic, (c) Europe, (d) China.

and regional variations with the intrinsic vertical variability of the forcing efficiency yields the total variability picture seen in Fig. 5a.

\section{Discussion}

The model mean direct $\mathrm{BC}$ forcing recalculated above is stronger than in previous estimates (Schulz et al., 2006; Feichter and Stier, 2012). This is mainly due to the fact that the host model for the efficiency profiles, OsloCTM2, has a high mean forcing efficiency compared to the others (Myhre et al.,
2013). The RF numbers in the present paper should therefore not be taken as new estimates for absolute direct RF forcing. We also observe that the recalculated RF values are highly correlated $(95 \%)$ with modeled burden values. This is again expected, and is due to the use of a common BC EP.

Different models will likely have different BC efficiency profiles, however we do not at present have enough information to estimate a model spread. A recent estimate using a column model (Zarzycki and Bond, 2010) shows forcing efficiencies above and below clouds comparable to the ones used in the present analysis. Hansen et al. (2005), using a 

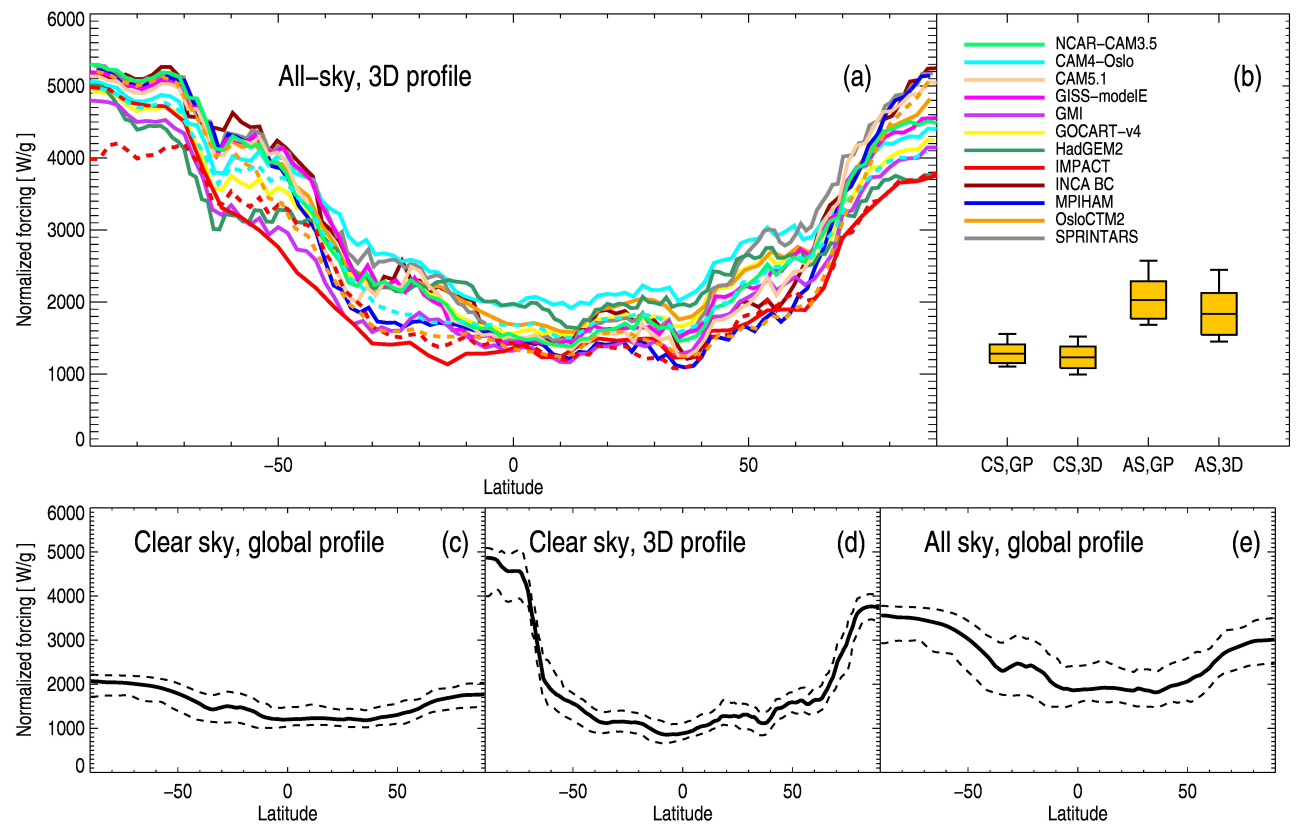

Fig. 5. Breakdown of spread in BC forcing efficiency. (a) Zonal mean of BC RF per unit mass using 3-D monthly resolved efficiency profiles and all sky conditions, for all models. Solid lines are results from AeroCom phase 2, dashed lines from phase 1. (c-e) Model mean (solid line) and maximum/minimum (dashed lines) when instead using (c) a global, annual mean efficiency profile and clear sky conditions, (d) 3-D profile and clear sky conditions, and (e) a global profile and all sky conditions. (b) shows the global mean values for the four cases. Boxes show one standard deviation on the model spread, whiskers show maximum/minimum values.

global climate model, show (their Fig. 27a) a forcing profile that is of similar shape to the one used here, but with somewhat weaker vertical gradient. However while the absolute strength of the forcing efficiency will matter for the final RF estimates, only the shape, which is related to how clouds and microphysics are treated in individual models, will influence the variability due to vertical profiles alone.

To attempt to quantify the sensitivity of the present analysis to the shape of the profile used, we reran the analysis with an EP that was weakened by $20 \%$ at the top of the atmosphere $(20 \mathrm{hPa})$ and unchanged at the surface, with a linear interpolation in between, resulting in an overall weaker EP gradient. This changed the global fraction of RF above $5 \mathrm{~km}$ by less than $5 \%$, indicating that the results are relatively stable within reasonable variations of the EP.

Results in the present study are given for total BC aerosol emissions only. However, due to different source regions, the vertical profiles of BCFF could be different from BC. Six models also provided concentration profiles for BCFF. Using the same efficiency profiles we performed the analysis also for BCFF, and found results consistent with what we have presented for BC (not shown). While the absolute forcing numbers differ due to lower total burdens for BCFF, the variability in vertical profiles is very similar to that for total BC. Our conclusions here are therefore also applicable to model comparison results on BCFF only.
Results presented here have all used emissions from year 2000. One model (CAM4-Oslo) also provided simulations for year 2006. While the BC burden was $60 \%$ higher for 2006 emissions, the forcing efficiencies and vertical profiles were invariant. This gives confidence that the variability due to vertical profiles can indeed be regarded as independent of that due to the present day emissions dataset.

Results for the P1 and P2 submissions of the IMPACT model, where no major aerosol microphysical changes have been performed, are quite similar. For OsloCTM2, however, where both an ageing scheme and modifications to the washout of BC were added, the forcing efficiency changes between P1 and P2 by as much as half of the full range observed. Hence, the transport scheme and model treatment of $\mathrm{BC}$ are crucial factors in determining the modeled value of forcing efficiency, and both of these factors are closely linked to the vertical distribution.

\section{Conclusions}

We have shown that the previously documented large spread in $\mathrm{BC}$ aerosol concentration profiles is enhanced for vertical $\mathrm{BC}$ RF profiles. Using 12 global aerosol models, we show that most models globally exert $40 \%$ of their BC forcing above $5 \mathrm{~km}$, and that regionally the fraction can be above $70 \%$. The spread between models is however quite large, and we computed that at least $20 \%$, possibly as much as 
$50 \%$, of the differences in modeled BC RF can be attributed to differences in vertical profiles. Harmonizing models with respect to the treatment of clouds, albedo and other factors relevant to the calculation of radiative forcing, is found to not be sufficient to remove this variability. To propose efficient mitigation measures for $\mathrm{BC}$, its radiative forcing needs to be well understood both in emission and transport regions. Further model improvements and comparisons with data are needed, and should focus on both of these types of region. Observational studies are needed to provide input to modelers, with the aim of better characterizing the global distribution of BC, especially in the upper troposphere. It is however clear that while the $\mathrm{BC}$ vertical profiles are important, they are not sufficient to explain all the remaining differences between global aerosol models. Further model intercomparison studies, e.g. on BC optical properties, surface albedo, treatment of clouds and aerosol transport and washout, are therefore also needed if the impact of $\mathrm{BC}$ on the global radiation balance is to be sufficiently constrained.

Acknowledgements. S. Ghan, X. Liu and R. Easter were funded by the US Department of Energy, Office of Science, Scientific Discovery through Advanced Computing (SciDAC) Program and by the Office of Science Earth System Modeling Program. Computing resources were provided by the Climate Simulation Laboratory at NCAR's Computational and Information Systems Laboratory (CISL), sponsored by the National Science Foundation and other agencies. The Pacific Northwest National Laboratory is operated for DOE by Battelle Memorial Institute under contract DE-AC06-76RLO 1830. Simulations of the ECHAM5-HAM, INCA, CAM4-Oslo and HadGEM2 models have been supported with funds from the FP6 project EUCAARI (Contract 34684). A. Kirkevag, T. Iversen and $\varnothing$. Seland (CAM4-Oslo) were supported by the Research Council of Norway through the EarthClim (207711/E10) and NOTUR/NorStore projects, by the Norwegian Space Centre through PM-VRAE, and through the EU projects PEGASOS and ACCESS. G. Myhre and B. Samset were funded by the Research Council of Norway through the EarthClim and SLAC projects. K. Tsigaridis and S. Bauer were supported by NASAMAP (NASA award NNX09AK32G). Resources supporting this work were provided by the NASA High-End Computing (HEC) Program through the NASA Center for Climate Simulation (NCCS) at Goddard Space Flight Center. N. Bellouin was supported by the Joint DECC/Defra Met Office Hadley Centre Climate Programme (GA01101). We also thank the two anonymous reviewers for their efforts.

Edited by: E. Highwood

\section{References}

Bellouin, N., Rae, J., Jones, A., Johnson, C., Haywood, J., and Boucher, O.: Aerosol forcing in the climate model intercomparison project (CMIP5) simulations by HADGEM2-ES and the role of ammonium nitrate, J. Geophys. Res.-Atmos., 116, D20206, doi:10.1029/2011jd016074, 2011.
Bian, H., Chin, M., Rodriguez, J. M., Yu, H., Penner, J. E., and Strahan, S.: Sensitivity of aerosol optical thickness and aerosol direct radiative effect to relative humidity, Atmos. Chem. Phys., 9, 2375-2386, doi:10.5194/acp-9-2375-2009, 2009.

Bond, T. C., Habib, G., and Bergstrom, R. W.: Limitations in the enhancement of visible light absorption due to mixing state, J. Geophys. Res.-Atmos., 111, D20211, doi:10.1029/2006jd007315, 2006.

Chin, M., Diehl, T., Dubovik, O., Eck, T. F., Holben, B. N., Sinyuk, A., and Streets, D. G.: Light absorption by pollution, dust, and biomass burning aerosols: A global model study and evaluation with aeronet measurements, Ann. Geophys., 27, 3439-3464, doi:10.5194/angeo-27-3439-2009, 2009.

Dentener, F., Kinne, S., Bond, T., Boucher, O., Cofala, J., Generoso, S., Ginoux, P., Gong, S., Hoelzemann, J. J., Ito, A., Marelli, L., Penner, J. E., Putaud, J.-P., Textor, C., Schulz, M., van der Werf, G. R., and Wilson, J.: Emissions of primary aerosol and precursor gases in the years 2000 and 1750 prescribed data-sets for AeroCom, Atmos. Chem. Phys., 6, 4321-4344, doi:10.5194/acp-64321-2006, 2006.

Editorial, Nature: Time for early action, Nature, 460, doi:10.1038/460012a, 2009.

Feichter, J. and Stier, P.: Assessment of black carbon radiative effects in climate models, Clim. Change, 3, 359-370, doi:10.1002/wcc.180, 2012.

Grieshop, A. P., Reynolds, C. C. O., Kandlikar, M., and Dowlatabadi, H.: A black-carbon mitigation wedge, Nature Geosci., 2, 533-534, doi:10.1038/Ngeo595, 2009.

Hansen, J., Sato, M., Ruedy, R., Lacis, A., and Oinas, V.: Global warming in the twenty-first century: An alternative scenario, P. Natl. Acad. Sci. USA, 97, 9875-9880, 2000.

Hansen, J., Sato, M., Ruedy, R., Nazarenko, L., Lacis, A., Schmidt, G. A., Russell, G., Aleinov, I., Bauer, M., Bauer, S., Bell, N., Cairns, B., Canuto, V., Chandler, M., Cheng, Y., Del Genio, A., Faluvegi, G., Fleming, E., Friend, A., Hall, T., Jackman, C., Kelley, M., Kiang, N., Koch, D., Lean, J., Lerner, J., Lo, K., Menon, S., Miller, R., Minnis, P., Novakov, T., Oinas, V., Perlwitz, J., Perlwitz, J., Rind, D., Romanou, A., Shindell, D., Stone, P., Sun, S., Tausnev, N., Thresher, D., Wielicki, B., Wong, T., Yao, M., and Zhang, S.: Efficacy of climate forcings, J. Geophys. Res.Atmos., 110, D18104, doi:10.1029/2005jd005776, 2005.

Haywood, J. M. and Shine, K. P.: Multi-spectral calculations of the direct radiative forcing of tropospheric sulphate and soot aerosols using a column model, Q. J. Roy. Meteor. Soc., 123, 1907-1930, 1997.

Kirkevåg, A. and Iversen, T.: Global direct radiative forcing by process-parameterized aerosol optical properties, J. Geophys. Res.-Atmos., 107, 4433, doi:10.1029/2001jd000886, 2002.

Kirkevåg, A., Iversen, T., Seland, Ø., Hoose, C., Kristjáson, J. E., Struthers, H., Ekman, A., Ghan, S., Griesfeller, J., Nilsson, D., and Schulz, M.: Aerosol-climate interactions in the Norwegian Earth System Model - NorESM1-M, Geosci. Model Dev., 6, 207-244, doi:10.5194/gmd-6-207-2013, 2013.

Koch, D., Schulz, M., Kinne, S., McNaughton, C., Spackman, J. R., Balkanski, Y., Bauer, S., Berntsen, T., Bond, T. C., Boucher, O., Chin, M., Clarke, A., De Luca, N., Dentener, F., Diehl, T., Dubovik, O., Easter, R., Fahey, D. W., Feichter, J., Fillmore, D., Freitag, S., Ghan, S., Ginoux, P., Gong, S., Horowitz, L., Iversen, T., Kirkevag, A., Klimont, Z., Kondo, Y., Krol, M., Liu, 
X., Miller, R., Montanaro, V., Moteki, N., Myhre, G., Penner, J. E., Perlwitz, J., Pitari, G., Reddy, S., Sahu, L., Sakamoto, H., Schuster, G., Schwarz, J. P., Seland, O., Stier, P., Takegawa, N., Takemura, T., Textor, C., van Aardenne, J. A., and Zhao, Y.: Evaluation of black carbon estimations in global aerosol models, Atmos. Chem. Phys., 9, 9001-9026, doi:10.5194/acp-9-9001-2009, 2009.

Koch, D., Balkanski, Y., Bauer, S. E., Easter, R. C., Ferrachat, S., Ghan, S. J., Hoose, C., Iversen, T., Kirkevåg, A., Kristjansson, J. E., Liu, X., Lohmann, U., Menon, S., Quaas, J., Schulz, M., Seland, Ø., Takemura, T., and Yan, N.: Soot microphysical effects on liquid clouds, a multi-model investigation, Atmos. Chem. Phys., 11, 1051-1064, doi:10.5194/acp-11-1051-2011, 2011a.

Koch, D., Bauer, S. E., Del Genio, A., Faluvegi, G., McConnell, J. R., Menon, S., Miller, R. L., Rind, D., Ruedy, R., Schmidt, G. A., and Shindell, D.: Coupled aerosol-chemistry-climate twentieth-century transient model investigation: Trends in shortlived species and climate responses, J. Climate, 24, 2693-2714, doi:10.1175/2011jcli3582.1, 2011b.

Koffi, B., Schulz, M., Breon, F. M., Griesfeller, J., Winker, D., Balkanski, Y., Bauer, S., Berntsen, T., Chin, M. A., Collins, W. D., Dentener, F., Diehl, T., Easter, R., Ghan, S., Ginoux, P., Gong, S. L., Horowitz, L. W., Iversen, T., Kirkevag, A., Koch, D., Krol, M., Myhre, G., Stier, P., and Takemura, T.: Application of the caliop layer product to evaluate the vertical distribution of aerosols estimated by global models: Aerocom phase I results, J. Geophys. Res.-Atmos., 117, D10201, doi:10.1029/2011jd016858, 2012.

Lamarque, J. F., Emmons, L. K., Hess, P. G., Kinnison, D. E., Tilmes, S., Vitt, F., Heald, C. L., Holland, E. A., Lauritzen, P. H., Neu, J., Orlando, J. J., Rasch, P. J., and Tyndall, G. K.: Cam-chem: Description and evaluation of interactive atmospheric chemistry in the community earth system model, Geosci. Model Dev., 5, 369-411, doi:10.5194/gmd-5-369-2012, 2012.

Lin, G., Penner, J., Sillmann, S., Taraborrelli, D., and Lelieveld, J.: Global modeling of soa formation from dicarbonyls, epoxides, organic nitrates and peroxides, Atmos. Chem. Phys., 12, 47434774,10 ,

http://www.atmos-chem-phys.net/12/4743/10/.5194/acp-124743-2012, 2012.

Liu, X., Easter, R. C., Ghan, S. J., Zaveri, R., Rasch, P., Shi, X., Lamarque, J.-F., Gettelman, A., Morrison, H., Vitt, F., Conley, A., Park, S., Neale, R., Hannay, C., Ekman, A. M. L., Hess, P., Mahowald, N., Collins, W., Iacono, M. J., Bretherton, C. S., Flanner, M. G., and Mitchell, D.: Toward a minimal representation of aerosols in climate models: Description and evaluation in the community atmosphere model cam5, Geosci. Model Dev., 5, 709-739, 10.5194/gmd-5-709-2012, 2012.

Liu, X. H., Penner, J. E., and Herzog, M.: Global modeling of aerosol dynamics: Model description, evaluation, and interactions between sulfate and nonsulfate aerosols, J. Geophys. Res.Atmos., 110, D18206, doi:10.1029/2004jd005674, 2005.

Myhre, G., Berntsen, T. K., Haywood, J. M., Sundet, J. K., Holben, B. N., Johnsrud, M., and Stordal, F.: Modeling the solar radiative impact of aerosols from biomass burning during the southern african regional science initiative (safari-2000) experiment, J. Geophys. Res.-Atmos., 108, 8501, doi:10.1029/2002jd002313, 2003.
Myhre, G., Samset, B. H., Schulz, M., Balkanski, Y., Bauer, S., Berntsen, T. K., Bian, H., Bellouin, N., Chin, M., Diehl, T., Easter, R. C., Feichter, J., Ghan, S. J., Hauglustaine, D., Iversen, T., Kinne, S., Kirkevåg, A., Lamarque, J.-F., Lin, G., Liu, X., Lund, M. T., Luo, G., Ma, X., van Noije, T., Penner, J. E., Rasch, P. J., Ruiz, A., Seland, Ø., Skeie, R. B., Stier, P., Takemura, T., Tsigaridis, K., Wang, P., Wang, Z., Xu, L., Yu, H., Yu, F., Yoon, J.-H., Zhang, K., Zhang, H., and Zhou, C.: Radiative forcing of the direct aerosol effect from AeroCom Phase II simulations, Atmos. Chem. Phys., 13, 1853-1877, doi:10.5194/acp-13-18532013, 2013.

Ramanathan, V. and Carmichael, G.: Global and regional climate changes due to black carbon, Nature Geosci., 1, 221-227, doi:10.1038/ngeo156, 2008.

Samset, B. H. and Myhre, G.: Vertical dependence of black carbon, sulphate and biomass burning aerosol radiative forcing, Geophys. Res. Lett., 38, L24802 doi:10.1029/2011g1049697, 2011.

Schulz, M., Textor, C., Kinne, S., Balkanski, Y., Bauer, S., Berntsen, T., Berglen, T., Boucher, O., Dentener, F., Guibert, S., Isaksen, I. S. A., Iversen, T., Koch, D., Kirkevag, A., Liu, X., Montanaro, V., Myhre, G., Penner, J. E., Pitari, G., Reddy, S., Seland, Ø., Stier, P., and Takemura, T.: Radiative forcing by aerosols as derived from the aerocom present-day and pre-industrial simulations, Atmos. Chem. Phys., 6, 5225-5246, doi:10.5194/acp-6-5225-2006, 2006.

Schwarz, J. P., Spackman, J. R., Gao, R. S., Watts, L. A., Stier, P., Schulz, M., Davis, S. M., Wofsy, S. C., and Fahey, D. W.: Global scale black carbon profiles observed in the remote atmosphere and compared to models, Geophys. Res. Lett., 37, L18812, doi:10.1029/2010GL044372, 2010.

Shindell, D., Kuylenstierna, J. C. I., Vignati, E., van Dingenen, R., Amann, M., Klimont, Z., Anenberg, S. C., Muller, N., JanssensMaenhout, G., Raes, F., Schwartz, J., Faluvegi, G., Pozzoli, L., Kupiainen, K., Hoglund-Isaksson, L., Emberson, L., Streets, D., Ramanathan, V., Hicks, K., Oanh, N. T. K., Milly, G., Williams, M., Demkine, V., and Fowler, D.: Simultaneously mitigating near-term climate change and improving human health and food security, Science, 335, 183-189, doi:10.1126/science.1210026, 2012.

Shindell, D. T., Chin, M., Dentener, F., Doherty, R. M., Faluvegi, G., Fiore, A. M., Hess, P., Koch, D. M., MacKenzie, I. A., Sanderson, M. G., Schultz, M. G., Schulz, M., Stevenson, D. S., Teich, H., Textor, C., Wild, O., Bergmann, D. J., Bey, I., Bian, H., Cuvelier, C., Duncan, B. N., Folberth, G., Horowitz, L. W., Jonson, J., Kaminski, J. W., Marmer, E., Park, R., Pringle, K. J., Schroeder, S., Szopa, S., Takemura, T., Zeng, G., Keating, T. J., and Zuber, A.: A multi-model assessment of pollution transport to the arctic, Atmos. Chem. Phys., 8, 5353-5372, doi:10.5194/acp-85353-2008, 2008.

Skeie, R. B., Berntsen, T., Myhre, G., Pedersen, C. A., Strom, J., Gerland, S., and Ogren, J. A.: Black carbon in the atmosphere and snow, from pre-industrial times until present, Atmos. Chem. Phys., 11, 6809-6836, doi:10.5194/acp-11-6809-2011, 2011.

Stier, P.: Host model uncertainties in aerosol radiative forcing estimates: Results from the aerocom prescribed intercomparison study, Atmos. Chem. Phys. Discuss., 12, 25487-25549, doi:10.5194/acpd-12-25487-2012, 2012.

Szopa, S., Balkanski, Y., Schulz, M., Bekki, S., Cugnet, D., Fortems-Cheiney, A., Turquety, S., Cozic, A., Deandreis, C., 
Hauglustaine, D., Idelkadi, A., Lathiere, J., Marchand, M., Yan, N., and Dufresne, J.-L.: Aerosol and ozone changes as forcing for climate evolution between 1850 and 2100, Clim. Dynam., doi:10.1007/s00382-012-1408-y, 2012.

Takemura, T., Nozawa, T., Emori, S., Nakajima, T. Y., and Nakajima, T.: Simulation of climate response to aerosol direct and indirect effects with aerosol transport-radiation model, J. Geophys. Res.-Atmos., 110, D02202, doi:10.1029/2004jd005029, 2005.

Textor, C., Schulz, M., Guibert, S., Kinne, S., Balkanski, Y., Bauer, S., Berntsen, T., Berglen, T., Boucher, O., Chin, M., Dentener, F., Diehl, T., Easter, R., Feichter, H., Fillmore, D., Ghan, S., Ginoux, P., Gong, S., Kristjansson, J. E., Krol, M., Lauer, A., Lamarque, J. F., Liu, X., Montanaro, V., Myhre, G., Penner, J., Pitari, G., Reddy, S., Seland, O., Stier, P., Takemura, T., and Tie, X.: Analysis and quantification of the diversities of aerosol life cycles within aerocom, Atmos. Chem. Phys., 6, 1777-1813, doi:10.5194/acp-6-1777-2006, 2006.

Textor, C., Schulz, M., Guibert, S., Kinne, S., Balkanski, Y., Bauer, S., Berntsen, T., Berglen, T., Boucher, O., Chin, M., Dentener, F., Diehl, T., Feichter, J., Fillmore, D., Ginoux, P., Gong, S., Grini, A., Hendricks, J., Horowitz, L., Huang, P., Isaksen, I. S. A., Iversen, T., Kloster, S., Koch, D., Kirkevag, A., Kristjansson, J. E., Krol, M., Lauer, A., Lamarque, J. F., Liu, X., Montanaro, V., Myhre, G., Penner, J. E., Pitari, G., Reddy, M. S., Seland, O., Stier, P., Takemura, T., and Tie, X.: The effect of harmonized emissions on aerosol properties in global models - an aerocom experiment, Atmos. Chem. Phys., 7, 4489-4501, doi:10.5194/acp-7-4489-2007, 2007.
Zarzycki, C. M. and Bond, T. C.: How much can the vertical distribution of black carbon affect its global direct radiative forcing?, Geophys Res Lett, 37, L20807, doi:10.1029/2010g1044555, 2010.

Zhang, K., O’Donnell, D., Kazil, J., Stier, P., Kinne, S., Lohmann, U., Ferrachat, S., Croft, B., Quaas, J., Wan, H., Rast, S., and Feichter, J.: The global aerosol-climate model echam-ham, version 2: Sensitivity to improvements in process representations, Atmos. Chem. Phys., 12, 8911-8949, doi:10.5194/acp-12-89112012, 2012. 